\title{
Preterm Birth at the Community University Hospital Center (Central African Republic)
}

\author{
A. Koirokpi' ${ }^{1}$, G. R. D. L. Kogboma Wongo ${ }^{1}$, N. R. Ngbale ${ }^{1}$, S. Ouapou ${ }^{1}$, \\ S. Matoulou-Mbala-Wa-Ngogbe1, W. H. Komaria Mballa1, \\ J. D. D. Longo' ${ }^{2}$ A. Sepou ${ }^{1}$ \\ ${ }^{1}$ Gynaecology-Obstetrics Service of the Bangui Community Hospital, Bangui, Central African Republic \\ ${ }^{2}$ Department of Public Health of the University of Bangui, Bangui, Central African Republic \\ Email: *ngbaler@yahoo.fr
}

How to cite this paper: Koirokpi, A., Kogboma Wongo, G.R.D.L., Ngbale, N.R., Ouapou, S., Matoulou-Mbala-Wa-Ngogbe, S., Komaria Mballa, W.H., Longo, J.D.D. and Sepou, A. (2020) Preterm Birth at the Community University Hospital Center (Central African Republic). Open Journal of Obstetrics and Gynecology, 10, 886-891. https://doi.org/10.4236/ojog.2020.1070083

Received: June 12, 2020

Accepted: July 7, 2020

Published: July 10, 2020

Copyright $\odot 2020$ by author(s) and Scientific Research Publishing Inc. This work is licensed under the Creative Commons Attribution International License (CC BY 4.0).

http://creativecommons.org/licenses/by/4.0/ (c) (i) Open Access

\begin{abstract}
The preterm Birth is the main cause of hospitalizing in the pathologic pregnancy service because of its deadly and morbidity rate observing into new born. The purpose of this Study: The purpose of this study is to study the epidemiology, clinic and prediction of preterm delivery in the Maternity at the community university hospital Center. Methodology: Over a 12 month period, we conducted a descriptive and analytical cross-sectional study of preterm delivery cases in the obstetrics and gynecology clinic of the community university hospital Center. The data was collected from the survey records and then analyzed by Epi Info version 3.5.4. Results: The preterm delivery rate related to delivery in the pregnancy pathology department was $17.5 \%$. A high proportion was noticed on patients aged from 20 - 24 years old (28.2\%), single (95.8\%) and pauciparous (39.5\%) were observed. Pelvic pain is the main cause of consultation (100\%). $83.1 \%$ of the cases were cured by Nifedipine. The higher neonatal mortality is in the pregnancy period less than 30 weeks, with statistically significant difference. Conclusion: Preterm birth is a common disease in the Department. It's more about young unmarried women. Neonatal mortality is higher Among pregnant women less than 30 weeks of pregnancy.
\end{abstract}

\section{Keywords}

Preterm Birth, Epidemiology, Prediction, Bangui

\section{Introduction}

Preterm Birth (TPB) refers to pregnancy complications between the 22nd and 36th weeks of pregnancy (amenorrhia week). This is the main reason for hospi- 
talization during the pregnancy [1] [2] [3]. This is the main cause of infant death in the world (around the four weeks of Life). [4] [5] [6]. In Africa and Asia, about 11 million people which is $85 \%$ are born prematurely every year, while in Europe and North America, 0.5 million people are born prematurely [4]. Even in developed countries, preterm birth is a major issue, because in developed countries, these children are treated in tertiary delivery rooms equipped with well-equipped newborn recovery services. Therefore, preterm birth remains one of the concerns of gynecologists, pediatricians and families due to their morbidity and mortality. This issue is particularly important in developing countries, including the Central African Republic, which do not always have access to modern neonatal recovery technologies. In Africa, especially in the Central African Republic, there are very few records of preterm birth, so the purpose of this study is to study epidemiological and clinical problems, as well as the prognosis of preterm birth in the community university hospital center.

\section{Methodology}

\subsection{Population Study}

That was an interdisciplinary, descriptive and analytical study conducted at the Community University hospital Center pregnancy pathology department. The meeting lasted for 12 months, from January 1st 2018 to December 31st 2019. The subjects were women between the 22nd and 36th weeks of pregnancy whose gestational age was between 22 and 36 weeks, and who were at risk of preterm birth and delivery. The Sample size is observed with all of the women who came for sign of preterm birth.

\subsection{Data Collection and Analysis}

The data were collected from a quiz based on the medical records of pregnant women at risk of preterm birth. The following Variables have been studied: the patient Age, the marital status, the parity, the pregnancy age, the clinical signs and the foetal prognostics. We submitted our form in the form of a frequency table. The proportion of each group was compared by chi $^{2}$ test or Fisher test. Only a percentage difference of less than $5 \% \mathrm{P}$ is considered statistically significant.

\section{Results}

In our study, we recorded a total of 71 cases of preterm birth over a total of 405 cases of Risk of Preterm Birth which is Rates at $17.5 \%$.

The highest proportion of the population is in the $20-24$ age group. Most of the deliveries were made by single mothers $95.8 \%$ and $47.9 \%$ by girl students (Table 1). Premature birth is a common phenomenon among the pauciparous. The pregnancy age of most pregnant women is between 30 and 36 years old (79\%) (Table 2). Pelvic pain was a common symptom in all pregnancies, followed by watery diarrhea $(38.6 \%)$. In $83.1 \%$ of cases, the risk of preterm birth is higher 
than or equal to 3 (Table 3 ). All pregnant women with three or more IMAPS received nifedipine as a genital toxin $83.1 \%$ and the etiologic treatment. The main causes of preterm birth were dominated by malaria $55 \%$ and the urinary infection $33 \%$. We registered 16 cases of neonatal newborn who died which is $22.5 \%$. Deliveries less than 30 Amenorrhea weeks (AW) of pregnancy are more at risk than newborns who die on their seven days of life (Table 4).

Table 1. Distribution of pregnant women according to the ages, marital status, social status.

\begin{tabular}{|c|c|c|}
\hline Parameters & Rate & Percentage \\
\hline \multicolumn{3}{|l|}{ Age } \\
\hline $16-19$ years old & 19 & 26.8 \\
\hline $20-24$ years old & 20 & 28.2 \\
\hline 25 - 29 years old & 18 & 25.4 \\
\hline 30 - 34 years old & 6 & 8.4 \\
\hline 35 - 39 years old & 6 & 8.4 \\
\hline$>39$ years old & 2 & 2.8 \\
\hline \multicolumn{3}{|l|}{ Marital status } \\
\hline Singles & 68 & 95.8 \\
\hline Marries & 3 & 4.2 \\
\hline \multicolumn{3}{|l|}{ Social status } \\
\hline Students & 34 & 47.9 \\
\hline Housewives & 19 & 26.8 \\
\hline Traders & 13 & 18.3 \\
\hline Employees & 5 & 7.0 \\
\hline
\end{tabular}

Table 2. Distribution of pregnant women according to the parity and the pregnancy age in amenorrhea weeks.

\begin{tabular}{ccc}
\hline Parameters & $\begin{array}{c}\text { Rate } \\
(\mathrm{n}=71)\end{array}$ & Percentage \\
Parity & 27 & 38 \\
Primiparous & 28 & 39.5 \\
Pauciparous & 13 & 18.3 \\
Multiparous & 3 & 4.2 \\
Big multiparous & & \\
Pregnancy age in AW & 15 & $21 \%$ \\
$22-29$ AW & 56 & $79 \%$ \\
$30-36$ AW & & \\
\hline
\end{tabular}


Table 3. Distribution of pregnant women according to the checking goal and the proof of the threat of preterm birth.

\begin{tabular}{ccc}
\hline Parameters & $\begin{array}{c}\text { Rate } \\
(\mathrm{n}=71)\end{array}$ & Percentage \\
\hline Clinical signs & 71 & 100 \\
Pelvic pain & 27 & 38.6 \\
Hydrorrhea & 17 & 24.3 \\
Genital hemorrhagia & & \\
Proof of threat of preterm birth & 12 & 16.9 \\
$<3$ & 20 & 28.1 \\
Between 3 and 6 & 39 & 55 \\
\hline 6 & &
\end{tabular}

Table 4. Distribution according to the pregnancy age in amenorrhea week and the new-born state at the neonatal precocious time.

\begin{tabular}{cccc}
\hline Parameters & Dead & Alive & p \\
\hline Age en AW & & & \\
22 AW -29 AW & 13 & 2 & \\
$30 \mathrm{AW}-36 \mathrm{AW}$ & 3 & 53 & 0.000 \\
\hline
\end{tabular}

\section{Discussion}

This study cannot be generalized because it is a hospital study.

The Risk of preterm birth changes according to the studies. The proportion was $17.5 \%$, higher than the proportion found by sy in Conakry in 2010 (3.3\%) [7]. Many studies have identified maternal age as a risk factor for preterm birth and delivery [5] [8]. Extreme ages (under 18 and over 35) are considered to be contributing to the increased risk of premature birth [9]. In our study, the most concerned was under the age of 25 (55\%. In Conakry, sy found that women aged 35 to 39 were the majority. Although Gillard et al. believe that the relationship between young people and early childbirth seems controversial, they believe that the risk of women under the age of 18 seems to be more [10].

Single women are recognized as risk factors for preterm birth [5] [8] [11]. Most of the pregnant women we studied were single while in Conakry, the author finds that the majority of women are married [7]. The reason for this difference is that in most West African countries, society cannot tolerate pregnancy outside marriage.

There is evidence that fatigue, physical stress, hard work conditions and low socio-economic levels are factors that contribute to the threat of preterm birth and early childbirth [5] [8] [11]. Almost half of the deliveries in our study were students. Their situation is precarious because they have to balance their studies with the needs of their future mothers. As most of these students/female college students live under the control of their parents with other family burdens, this instability is even more serious. In their results, other authors found that housewives dominate [7] [8]. 
Housewives often engage in heavy manual labor. Fatigue and trauma often have an impact on the threat of preterm birth [11] [12]. Multiplicity is considered to be a risk factor for threat occurrence [11]. This trend has not been reflected in our research, and we have noticed that pauciparous is the dominant phenomenon in our research.

Most of the newborn children were between 30 to 36 gestational weeks in Brazzaville, Pambou found that $52 \%$ of preterm births occurred between the ages of 34 and 36. As for sy, the majority of preterm births (76.4\%) in the series occurred between $30 \mathrm{AW}$ and $33 \mathrm{AW}$ [7].

At the time of admission, $83.1 \%$ of pregnant women had the Risk of Preterm Birth greater than or equal to 3 . These high rates are due to the fact that pregnant women often come with advanced clinical stages (Table 3 ).

The purpose of genital toxin is to prevent uterine contraction. The goal is to try to delay childbirth in order to improve the morbidity and mortality of newborns, sometimes reducing the childbirth rate from a few hours to a few days [10] [13]. In $83.1 \%$ of the cases, we decided to extend the gestational period by using nifedipine to pregnant women. Some of the authors used nifedipine in the study and successfully prolonged the pregnancy by 48 hours [7] [14] [15] [16] [17]. The Central African Republic is a country where malaria is dominated that is why the main cause of preterm birth is the malaria.

Neonatal mortality and morbidity are closely related to gestational period [1] [2]. The results of our study show that the mortality rate of premature infants with a gestational period of $22-29$ weeks is higher, and there is a statistically significant difference: $\mathrm{p}<0.001$ (Table 4).

\section{Conclusion}

According to this study, we found that early childbirth is common among young, single, pauciparous and most housewives. The trend towards treatment depends on the serious threat of early childbirth. Since our work does not cover all aspects of preterm birth, more in-depth studies are necessary to better understand the relevant factors.

\section{Conflicts of Interest}

The authors declare no conflicts of interest regarding the publication of this paper.

\section{References}

[1] Lansac, J. (2002) Recommandations pour la pratique clinique: Menace d'Accouchement Prématuré à membranes intactes. The Journal de Gynécologie Obstétrique et Biologie de la Reproduction, 7, 5S7-2S1128.

[2] Cabrol, D., Goffinet F., Carbonne, B., Dreyfus, M. and D’Ercole, C. (2002) Recommandations pour la pratique clinique: La menace d'accouchement prématuré (MAP) à membranes intactes. The Journal de Gynécologie Obstétrique et Biologie de la Reproduction, 7, 5S7-2S1128. 
[3] Ancel, P.Y. (2002) Menace d'accouchement prématuré et travail prématuré à membranes intactes: Physiopathologie, facteurs de risque et conséquences. The Journal de Gynécologie Obstétrique et Biologie de la Reproduction, 7, 10-21.

[4] Beck, S., Wojdyla, D., Say, L., Betran, A.P., Merialdi, M., Requejo, J.H., Ruben, C., Menon, R. and Van look, P.F. (2010) The Worldwide Incidence of Preterm Birth: A Systematic Review of Maternal Mortality. Bulletin of the World Health Organization, 88, 31-38. https://doi.org/10.2471/BLT.08.062554

[5] Pambou, O., Ntsika-Kaya, P., Ekoundzola, J.R. and Mayanda, F. (2006) Naissance avant terme au CHU de Brazzaville. Cahier d'Etude et de Recherche Francophone, 16, 185-189.

[6] Blencowe, H., Cousens, S., Oestergaard, M.Z., Chou, D., Moller, A.B., Narwal, R., Adler, A., Garcia, C.V., Rohde, S., Say, L. and Lawn, J.E. (2012) National, Regional and Worldwide Estimates of Preterm Birth Rates in the Year 2010 with Time Trends Since 1990 for Selected Countries: A Systematic Analysis and Implications. The Lancet, 379, 2162-2172. https://doi.org/10.1016/S0140-6736(12)60820-4

[7] Sy, T., Diallo, F.B., Diallo, Y., Camara, M.K., Diallo, A., Cissoko, M., Lontsi, G.R. and Diallo, M.S. (2010) Menaces d'accouchement prématuré: Utilisation de la Nifédipine à Conakry, Guinée. Médecine Tropicale, 70, 141-144.

[8] Courbiere, B. and Carcopino, X. (2015) La référence gynécologie Obstétrique ECN. Vernazobres-Grego, Paris, 622 p.

[9] Merger, R., Levy, J. and Melchior, J. (2001) Accouchementprématuré Précis d'Obstétrique, 6eme Edition, Masson, Paris, 597 p.

[10] Gillard, P., Biquard, F., Sentilhes, L. and Descamps, P. (2008) Menace d'accouchement prématuré. In Lansac, J. and Magnin, G., Eds., Obstétrique pourle Praticien, 5e Edition, Masson, Belgique, 311-322.

[11] Kayem, G., Goffinet, F., Tsatsaris, V. and Cabrol, D. (2003) Menace d'accouchement prématuré: Diagnostic et prise en charge. Traité d'Obstétrique, 1re Edition, Flammarion, Paris, 422-451.

[12] Rakotonirina, E.J., Randriamialy, L.L., Andriamifidison, R.N.Z., Ravaoarisoa, L., Andrianampanalinarivo, H.R., Rakotomanga, J.D.M. and Ranjalahy, R.J. (2013) Conditions professionnelles associées à l'accouchement prématuré à Antanarivo: Etude cas-témoins. Medecine d Afrique Noire, 3, 145-150.

[13] Ndiaye, O., Gueye-Ba, M., Sylla, A., Gueye, M., Diene, J.F., Guelaye-Sall, M., Sarr, A., Ba, M. and Kuakuvi, N. (2009) Corticothérapie anténatale et pronostic du nouveau-né prématuré dans une clinique privée de DAKAR. Medecine d Afrique Noire, 2, 77-80.

[14] Carbonne, B. and Tsatsaris, V. (2002) Menace d'accouchement prématuré: Quels tocolytiques utiliser? The Journal de Gynécologie Obstétrique et Biologie de la Reproduction, 31, 5S96-5S104.

[15] Matis, R. (2008) Menace d'accouchement prématuré. Vocation Sage-Femme, 7, 18 p.

[16] Cabrol, D. (2002) Recommandations pour la Pratique clinique. The Journal de Gynécologie Obstétrique et Biologie de la Reproduction, 7, 5S7-2S1128.

[17] Kashanian, M., Akbarian, A.R. and Soltanzadeh, M. (2005) Atosiban et Nifédipine pour le traitement de la menace d'accouchement prématuré. The Journal de Gynécologie Obstétrique et Biologie de la Reproduction, 91, 10-14. 